\title{
Kirkpatrick's Model for Evaluation of Financial Management Training
}

\author{
Muhammad Ridha Albaar ${ }^{1 *}$, Maria Paristiowati ${ }^{2}$ \\ ${ }^{1}$ Department of Management Information, Academy of Computer Science (AIKOM) Ternate, Indonesia \\ ${ }^{2}$ Department of Chemistry Education, Jakarta State University, Jakarta, Indonesia \\ *Corresponding author. Email: ridha_fara13@yahoo.co.id
}

\begin{abstract}
This study aims to identify and describe the Regional Financial Management Training Program which in principle leads to improvement. The method used in this evaluation study is a quantitative descriptive method with a qualitative study. The research design used in this study was Kirkpatrick's model. This design was chosen because the Kirkpatrick model can evaluate training programs to determine whether the program can be continued, improved or stopped. Evaluation of the implementation of this training was conducted at the Human Resources Development Agency (BPSDM) of North Maluku Province, the number of respondents used was 40 people who were training participants. Based on the evaluation of the evaluation component aspects, it can be concluded that the evaluation of this training can be continued with improvements to improve the quality of training in the future. This research can be used as a recommendation for Public Administration Institutions (LAN) and BPSDM throughout Indonesia in order to increase ASN capacity for financial management.
\end{abstract}

Keywords: evaluation, training program, four levels

\section{INTRODUCTION}

Competent personnel resources are needed in the guidance system of government in accordance with national and global challenges. The issue of the competence of personnel is an important determinant of the apparatus memeiliki given double duty, as well as community service in a fair and transparent and also must be able to show loyalty, dedication and work ethic and integrity.

Human Resources Development Agency (BPSDM) North Maluku Province is one of the institutions that serve conduct educational activities and training of the ASN at the Provincial Government of North Maluku. Training or education and training is a learning process so that learners can develop their potential through the explanation and knowledge by using the theory and practice directly in the field. In accordance with the duties and functions of the outline BPSDM organizes two types of training activities, namely training of administrative and technical training. BPSDM North Maluku province besides managing administratively Training and Technical Training, BPSDM North Maluku province also manages technical training Financial Management.

Internal evaluation of the components that are directly involved in the program, while the external aspects include the contribution made by participants of the program on their work environment. Evaluation of training to differentiate on (a) the evaluation process and, (b) evaluation of the results and impact of training. Evaluation of an evaluation process performed on the steps of

activities from planning, implementation and end of training. The evaluation process is done to capture the opinion of all participants on widyaswara / resource, training participants, organizers, facilities and infrastructure, teaching materials / modules, services and so on. Evaluation of the results and impact of training marginally useful to determine and quantify the effects caused by an education and training.

Evaluation is an activity that includes measurement and assessment [1]. The evaluation model developed by Kirkpatrick was known as "Kirkpatrick four levels evaluation model". The evaluation of the effectiveness of training programs according to Kirkpatrick includes four levels of evaluation, namely: level 1-reaction, leval 2Learning, level 3- Behavior, level 4 - Result [2].

Sikula, defines that training is a short-term educational process that uses systematic and organized procedures, while non-managerial workforce learns technical knowledge and skills for specific purposes [3].

The following are relevant research related to finance and evaluation. Research conducted by Novi "The Effect of Financial Management System and Implementation of Regional Financial Accounting System Against Regional Financial Oversight Functions (Studies in the Department of Revenue Finance and Asset Management Area (DPPKAD) in Boyolali). This study shows that financial management systems affect the function of financial supervision [3].

Research with training programs with the Kirkpatrick model "Measuring E-Learning of The Standard Operating Course Course using the 1st and 2nd Levels of Kirkpatrick 
Model", this research is training research using the Kirkpatrick model using two levels that exist in the Kirkpatric Model, namely: (1 ) Level of Reaction, and (2) Level Learning, this study aims to measure the learning program organized by the Ministry of Religion Education and Training Center, in standard operational procedures (SOP) training [5].

Related to the methodology, Omer use Kirckpatrick in the research entitled "Through Krickpatrick Program Evaluation Framework". Research results demonstrate that the model of Kirkpatrick is an evaluation tool to learn that change mental models and ways of thinking. Regarding the research education program memerlihatkan any changes in knowledge, changes in the ability of students, changing the structure of education, and improving leadership in education [6].

Searches through the relevant research should be emphasized that this study is the first study in the Kirckpatrick models, which are specifically related to the Program Evaluation Financial Management Training On Human Resources Development Agency of North Maluku province.

\section{METHODS}

The study aims to assess the evaluation more objective about the successes and constraints that result not maximal Financial Management Training program On the Human Resources Development Agency of North Maluku province. The method used in this evaluation study is descriptive quantitative method with in-depth qualitative deepening. Researchers as an evaluator using survey data, observations, interviews and document research together in the analysis by comparing, integrating, to compare the results of these data [7]. The instrument used in this study are, questionnaire, interview, observation and document study. Quantitative data presented in the form of numbers, while the qualitative data in the form of words.In this study the respondents were 40 participants in regional education management training.

\section{RESULTS AND DISCUSSION}

Evaluation is done to answer questions and to implement indicators in determining the value or meaningfulness of something. Evaluation questions provide direction and basis for implementing evaluations, without which evaluators will lose the expected focus. Therefore, a program is needed to get the characteristics of the success of a program and is made for successful programs. Indicators are program characteristics which are considered as important relevant bases for conducting evaluation research. In this case, the indicators approved by financial management training are taken based on the criteria for effective and efficient training and training as follows:

\section{Achievement of Reaction Levels}

Based on the results of the research conducted for the reaction level, the average training participants were satisfied with the training curriculum, education and training staff and existing training facilities with a success rate above $50 \%$ where training participants gave a fairly good assessment based on nine indicators used to measure the success rate in reaction level, or in other words for the reaction level has met a good training standard. This statement is supported by

Widyoko's research that training programs are considered effective if the process can satisfy participants, satisfaction becomes a motivation for participants to take part in further training $[8,15]$. Silberman suggests that reaction evaluation is an evaluation of the training process, the quality of the process or implementation of a training can be measured through the level of satisfaction of the participants. the better the implementation of training, the better the participants' satisfaction with the implementation of training. However, the indicators used as the success rate of the program at the reaction level need to be improved in terms of the training curriculum, namely the training modules that are used are not in accordance with the standards of a good training module.

Table 1. Criteria for Program Success

\begin{tabular}{|c|c|c|}
\hline Stages & component & Indicator \\
\hline \multirow{9}{*}{ Reaction } & \multirow{4}{*}{ Curiculum } & Schedule \\
\hline & & Material \\
\hline & & Method \\
\hline & & Media \\
\hline & \multirow[b]{2}{*}{ Education Staff } & Widyaswara \\
\hline & & Committee \\
\hline & \multirow{3}{*}{ Facilities } & Classroom \\
\hline & & Dormitory \\
\hline & & $\begin{array}{l}\text { Supporting } \\
\text { facilities }\end{array}$ \\
\hline Learning & $\begin{array}{c}\text { Participant Evaluation } \\
\text { Results }\end{array}$ & $\begin{array}{l}100 \% \\
\text { participant } \\
\text { graduation rate } \\
\text { with } \\
\text { qualifications is } \\
\text { quite satisfying }\end{array}$ \\
\hline Behavior & $\begin{array}{c}\text { Changes in knowledge, } \\
\text { behavior and } \\
\text { competence }\end{array}$ & $\begin{array}{l}\text { Knowledge } \\
\text { Behavior } \\
\text { Competence }\end{array}$ \\
\hline Result & $\begin{array}{l}\text { Organizational } \\
\text { performance }\end{array}$ & Public Service \\
\hline
\end{tabular}

\section{Achievement of Learning Levels}

Evaluation of learning levels measures the learning outcomes of regional financial management training participants, based on $100 \%$ training participants 'graduation indicators with satisfactory qualifications, seen based on training participants' learning outcomes as evidenced by certificates, learning outcomes of 40 training participants as many as 12 people get very satisfactory ratings or $30 \%$, while 28 people get satisfactory ratings or $70 \%$.

While Eva's research on learning evaluation at this level the learning outcomes are in a good category, where learning outcomes are measured using pre-tests and test posts. 
after being compared that the results of the learning evaluation conducted by the researcher have not used the pre test so that there needs to be improvement, for the learning evaluation process so that the next training is pretest so that it can measure the training participants' initial abilities.

\section{Achievement of Behavior Levels}

The results of research on behavior evaluation showed a change in behavior of the alumni of the training after following regional financial management training. Evaluation of the application of aspects of knowledge falls into the good category. this aspect includes training participants following all procedures or knowledge obtained during training with a success rate of $84.5 \%$ (table 2).

Table 2. Knowledge

\begin{tabular}{|l|c|c|}
\hline \multicolumn{1}{|c|}{ Statement } & $\%$ & Category \\
\hline $\begin{array}{l}\text { Alumni follow the procedures } \\
\text { obtained at the training }\end{array}$ & 84,5 & Very good \\
\hline $\begin{array}{l}\text { Alumni implement knowledge } \\
\text { in units }\end{array}$ & 82 & Good \\
\hline $\begin{array}{l}\text { Various problems in the work } \\
\text { unit can be completed }\end{array}$ & 77,5 & Good \\
\hline $\begin{array}{l}\text { Alumni using knowledge for } \\
\text { development in the work unit }\end{array}$ & 82,5 & Good \\
\hline
\end{tabular}

Evaluation of the application of aspects of behavior change includes good categories. This aspect includes how to socialize with superiors and coworkers, the ability to cooperate, accept and give advice, and not force the will. To disclose this, a questionnaire and interviews were given to participants, superiors and coworkers. From the results of the questionnaire consisting of 18 (eighteen) items of statements and interviews, it was found that changes in the behavior of respondent training during the training were in a very good category, where training respondents respected honesty in each action based on $87.5 \%$ success rate, and regional financial management training of respondents can help create innovative ideas included in the good category based on the success rate of $77.5 \%$, and to accept the opinions of others who disagree this is supported by the statement that, after the respondent's training received less opinion from others with a level $50 \%$ success (table 3 ). Therefore respondent training at the time of participating in professional ethics training must be truly understood and applied how to respect the opinions of others even though it is different but differences that occur are common in an organization and as a benchmark for the progress of existing organizations.

To evaluate the application of competency aspects included in the good category. where the success rate is $82.50 \%$, where this aspect includes competency in arranging the stages of the program activities in the APBD, APBD-P, administration, accountability, goods management and directed supervision towards achieving goals, and for statements of training respondents providing good service to the public and coworkers are included in a very good category where the success rate obtained based on the questionnaire results is $85.5 \%$ (Table 4 ).

Table 3. Attitudes

\begin{tabular}{|l|c|c|}
\hline \multicolumn{1}{|c|}{ Statement } & \% & Category \\
\hline Alumni more fairness in action & 87,5 & $\begin{array}{l}\text { Verry } \\
\text { good }\end{array}$ \\
\hline $\begin{array}{l}\text { Alumni firmer in conveying } \\
\text { ideas }\end{array}$ & 80 & Good \\
\hline $\begin{array}{l}\text { Alumni are more consistent in } \\
\text { completing the task }\end{array}$ & 82,5 & Good \\
\hline $\begin{array}{l}\text { Alumni maintain compliance } \\
\text { with religious and moral values }\end{array}$ & 83 & Good \\
\hline Alumni more polite to behave & 82,5 & Good \\
\hline $\begin{array}{l}\text { Alumni more polite in spoken } \\
\text { word }\end{array}$ & 82,5 & Good \\
\hline $\begin{array}{l}\text { Alumni maintain tolerance in } \\
\text { the workplace }\end{array}$ & 85 & Verry \\
\hline $\begin{array}{l}\text { Alumni mood empathy in } \\
\text { relationships in the work unit }\end{array}$ & 77 & Good \\
\hline $\begin{array}{l}\text { Alumni in completing financial } \\
\text { management more focused }\end{array}$ & 77,5 & Good \\
\hline $\begin{array}{l}\text { Alumni present on time at the } \\
\text { workplace }\end{array}$ & 81 & Good \\
\hline $\begin{array}{l}\text { Alumni are serious in carrying } \\
\text { out activities }\end{array}$ & 81 & Good \\
\hline $\begin{array}{l}\text { Alumni are more committed to } \\
\text { the discipline }\end{array}$ & 78 & Good \\
\hline $\begin{array}{l}\text { Alumni coordinate more with } \\
\text { superiors }\end{array}$ & 84,5 & $\begin{array}{l}\text { Verry } \\
\text { Alumni are more in synergy } \\
\text { with coworkers }\end{array}$ \\
\hline $\begin{array}{l}\text { Alumni less receptive to the } \\
\text { opinions of others }\end{array}$ & 77,5 & Good \\
\hline $\begin{array}{l}\text { Alumni help create innovative } \\
\text { ideas }\end{array}$ & 77,5 & Good \\
\hline $\begin{array}{l}\text { Alumni were able to make } \\
\text { innovative suggestions }\end{array}$ & 77,5 & Good \\
\hline $\begin{array}{l}\text { Alumni were able to control } \\
\text { themselves in a situation }\end{array}$ & 80 & Good \\
\hline
\end{tabular}

Table 4. Skills

\begin{tabular}{|l|c|c|}
\hline \multicolumn{1}{|c|}{ Statement } & \% & Category \\
\hline $\begin{array}{l}\text { Alumni faster solve financial } \\
\text { problems }\end{array}$ & 79 & Good \\
\hline $\begin{array}{l}\text { Alumni faster solve financial } \\
\text { problems }\end{array}$ & 74 & Good \\
\hline $\begin{array}{l}\text { Alumni are able to arrange } \\
\text { stages in the APBD }\end{array}$ & 82,5 & Good \\
\hline Alumni giving good service & 85,5 & $\begin{array}{l}\text { Verry } \\
\text { Good }\end{array}$ \\
\hline
\end{tabular}

While research conducted by In Bagiyono, evaluation of behavior towards training teaching techniques capable of providing trainees behavior change, and even some of the 
alumni to provide information that the training materials are also useful in improving the quality of the presentation by the time they make a presentation of scientific paper [9]. Stephen's research, behavioral-based evaluations assess employees based on how they behave or act, based on criteria such as effort, commitment, teamwork, friendliness, and customer problem-solving abilities based on the results of measurable and achieved behavioral evaluations [10].

After comparing between research conducted by researchers and two studies that for behavioral evaluation of the average training there was a significant change in behavior after participants attended the training [12].

\section{Achievement of Results Evaluation}

Based on the results of the questionnaire and interviews with respondents in training, superiors and coworkers, data was obtained that overall from the organizational performance indicators in the category of both aspects of public services, which are described in 7 (seven) items, the impact generally included in the category of very well. This is based on the results of questionnaires and interviews with supervisors and co-workers of the education and training respondents, that the benefits of regional financial management training are to improve knowledge and skills in completing our regional financial administration management tasks, this statement is supported with an $85 \%$ success rate (Table 5), from respondents who gave a response to this statement, and its contribution to human resource development, especially financial managers to avoid mistakes and errors because of lack of understanding about regional financial management, and its efficiency can manage finances well so as to produce accountability reports on APBD implementation with successful achievement of program objectives the results of the Regional Head report [13].

Table 5. Result

\begin{tabular}{|l|c|c|}
\hline \multicolumn{1}{|c|}{ Statement } & \% & Category \\
\hline $\begin{array}{l}\text { The purpose of training has } \\
\text { been as needed }\end{array}$ & 80,5 & Good \\
\hline $\begin{array}{l}\text { Training has a positive effect in } \\
\text { resolving the financial } \\
\text { management }\end{array}$ & 85 & $\begin{array}{l}\text { Verry } \\
\text { Good }\end{array}$ \\
\hline $\begin{array}{l}\text { The support of the leadership is } \\
\text { very great for the training }\end{array}$ & 82,5 & Good \\
\hline $\begin{array}{l}\text { The quality of alumni getting } \\
\text { better }\end{array}$ & 82,5 & Good \\
\hline $\begin{array}{l}\text { Increase creativity and } \\
\text { innovation }\end{array}$ & 80 & Good \\
\hline An increase effectiveness in the & 82,5 & Good \\
\hline $\begin{array}{l}\text { Public confidence in } \\
\text { government's performance is } \\
\text { increasing }\end{array}$ & & \\
\hline
\end{tabular}

The results of the above research are supported by Basir's research, which focuses on assessing the results of impact evaluations aimed at assessments conducted by the community on the process of service provided after following training [11].
While the research conducted Bagiyono's research focuses on the final results that occur as an impact of the training program that has been followed, and not all impacts from the program can be measured and even if it can be measured it often takes a long time [9].

\section{CONCLUSION}

Based on the results of the above research, it can be concluded:

1. To evaluate the reaction level of training participants, they are satisfied or in the good category for the implementation of training programs implemented, but there are some things that need to be improved, especially in terms of training curriculum in providing training modules. where each material to be delivered must have a purpose and learning objectives from the material to be delivered.

2. For evaluation of learning has met the qualification standards of LAN, namely Graduating with a predicate is quite satisfactory, but for the future the organizer must pre-test in order to know the initial ability of training participants.

3. For Behavior Evaluation at the average level the training participants experienced a significant change in behavior in other words that the education and training alumni were able to implement everything obtained during the training activities carried out.

4. For Evaluation The results of this increase in organizational performance are good, especially in providing services to people who need information about finance.

\section{ACKNOWLEDGMENT}

This research work is supported by the North Moluccas Provincial Government

\section{REFERENCES}

[1] Arthur Riyan, Evaluation of Training Programs in Scientific Writing for Pusbangtendik Widyaswara Kemdikbud, Journal of Educational Research and Evaluation Vol 22, No 1, June 2018.

[2] Bagiyono. 2012. "Evaluation of Teaching Technique Training Based on Kirkpatrick's Training Four Evaluation Level Models". Electronic Proceedings National Seminar on Nuclear Technology HR: Center for Nuclear Information Development (PPIN) -BATAN Yogyakarta

[3] Basir Firman, Diklatpim IV Program Evaluation at Makassar Religious Education Training Center with Kirkpatrick's Model, Educational Evaluation Journal Vol 4, No. 2, 2013.

[4] Bateman, Snell, Management, Leading \& Collaborating in a Competitive World, Tenth Edition. New York: McGraw-Hill Companies, Inc. 2013. 
[5] Dessler,Gary, Human Reseource Management, Eight Edition. New Jersey. Prentice Hall, Inc. Upper Sadie River, 2000.

[6] Djaali and Pudji Muljono. Measurements in the Field of Education, Jakarta: Grasindo, 2008.

[7] Gall, Meredith D., Gall, Joyce dan Brog, Walter R. Educational Research: An Introduction. New York: Pearson Education, 2007.

[8] Gabriela dan Lynn McAlpine. (2016). "Helping teachers to focus on learning and reflect on their teaching what role does teaching contectx play?", Journal of Studies In Educational Evaluation, 48(2)

[9] Hania Amina, 2015, "Kirkpartick Evaluation Model in the Implementation of Training (Levels of Reaction and Learning) at the Perum Jakarta Education and Training Center", Indonesian Science Management Research Journal (JRMSI) Vol 6, No. 1,2015.

[10] Iskandar Azwar, Kirkpatrick Model ASN Training Evaluation (Case Study of Effective Negotiation
Skill Training at the Finance Center), Journal of Education Vol 20, No. 1, 2019

[11]Jarvis, Peter. Adult Education and Lifelong Learning: Theory and Pratice, 3rd edition. London: Routledge Palmer,2004.

[12] JodyL.Fitzpatrick, James R. Sanders, and Blaine R. Worthen, Program Evaluation: Alternative Approaches and Practical Guidelines.Boston: Pearson Education,2004.

[13] Miles,Mathew B., dan Huberman, A. Michael, Analisis Data Kualitatif, diterjemahkan oleh Tjetjep Rohendi Rohidi.Jakarta: UI-Press.

[14] Mochtar Kusuma, Educational Evaluation, Introduction, Competence and Implementation. Yogyakarta: Parama llmu, 2016.

[15] Paivi Atjonen, 2015. "Your career will be over, power and contradictions in the work of educational evaluators", Journal of Studies in Educational Evalution, 5.37. 